\title{
EDITORIAL
}

\section{From Rome to The Hague: Recent Developments on Immunity Issues in the ICC Statute}

Keywords: International Criminal Court; international criminal law; immunity; United States.

\begin{abstract}
Article 27 ICC Statute has proven to cause compatibility problems with regard to immunity provisions in national constitutions. States have, however, indicated readiness to overcome these problems. On the other hand, Article 98 forms the pivot of the latest attempt of the United States, a non-signatory state, to ensure a de facto immunity from ICC jurisdiction for US nationals. This editorial sets out the contrasting approach of states to the ICC and concludes that the US Proposal for a Rule to 98(2) would have had the effect that the rule encompassed in Article 27 ICC Statute would in practice not apply to nationals of non-state parties.
\end{abstract}

\section{INTRODUCTION}

To date the Rome Statute of the International Criminal Court (ICC) has secured 19 ratifications while in a large number of other states the ratification process has started. ${ }^{1}$ The road from Rome to The Hague is, however, not without obstacles. Two of these obstacles, related to the issue of immunity, will be discussed here. The ICC Statute contains two provisions on the question of immunity of individuals suspected of committing crimes falling within the jurisdiction of the Court. Article 27 and Article 98 read as follows:

\section{Article 27}

Irrelevance of official capacity

This Statute shall apply equally to all persons without any distinction based on official capacity. In particular, official capacity as a Head of State or Government, a member of a Government or parliament, an elected representative or a government official shall in no case exempt a person from criminal responsibility under this Statute, nor shall it, in and of itself, constitute a ground for reduction of sentence.

1. 109 states have signed the Statute while Senegal, Trinidad \& Tobago, San Marino, Italy, Fiji, Ghana, Norway, Belize, Tajikistan, Iceland, Venezuela, France, Belgium, Canada, Mali, Botswana, Lesotho, Luxembourg and New Zealand have ratified it. 60 ratifications are needed for the Statute to enter into force. See http://www.iccnow.org (last access date 12 September 2000) for further information.

13 Leiden Journal of International Law 485-493 (2000)

(10 2000 Kluwer Law International 
Immunities or special procedural rules which may attach to the official capacity of a person, whether under national or international law, shall not bar the Court from exercising its jurisdiction over such a person.

\section{Article 98}

Cooperation with respect to waiver of immunity and consent to surrender

The Court may not proceed with a request for surrender or assistance which would require the requested State to act inconsistently with its obligations under international law with respect to the State or diplomatic immunity of a person or property of a third State, unless the Court can first obtain the cooperation of that third State for the waiver of the immunity.

The Court may not proceed with a request for surrender which would require the requested State to act inconsistently with its obligations under international agreements pursuant to which the consent of a sending State is required to surrender a person of that State to the Court, unless the Court can first obtain the cooperation of the sending State for the giving of consent for the surrender.

Although these provisions were not among the most controversial ones debated in the Conference leading up to the conclusion of the Rome Statute on 17 July 1998 , both have recently been the subject of discussion. Article 27 causes constitutional problems for many states in the ratification process while Article 98 forms the pivot of the latest US attack on the jurisdictional provisions of the Statute. These developments, although not directly related, warrant integrated discussion because of their subject matter as well as the tellingly contrasting attitude of states towards the International Criminal Court presented by such a discussion.

\section{ARTICLE 27 ICC STATUTE}

In many states the ratification process has initiated a debate on the compatibility of the ICC Statute with constitutional provisions on, inter alia, the immunity of certain state officials. ${ }^{2}$ It is not argued that Article 27 contains bad law. Indeed, the Nuremberg Tribunal already considered that:

The principle of international law, which under certain circumstances, protects the representative of a state, cannot be applied to acts which are condemned as criminal by international law. The authors of these acts cannot shelter themselves behind their official position in order to be freed from punishment in appropriate proceedings. ${ }^{3}$

2. Other issues include the extradition of a state's own nationals and life imprisonment.

3. Nuremberg Judgment (IMT 1946), 41 AJIL 172, at 221 (1947). 
This principle has since then been confirmed on several occasions and is reflected in Article 7(2) of the ICTY Statute and Article 6(2) of the ICTR Statute as well. ${ }^{4}$ However, the ICC Statute undeniably has implications for constitutional immunities of state officials, especially since Article 27 is not confined to the defence of immunity before the Court but also provides that official capacity does not affect the applicability of the Statute, which includes the obligations resting on state parties to co-operate and provide judicial assistance. Crucially, Article 89 ICC Statute obliges states to comply with the request of arrest and surrender of persons found on their territory. The constitutional problems caused by Article 27 are epitomised by the decision of the French Conseil Constitutionnel of 22 January 1999. The Court held, inter alia, that the immunity granted to the President of the Republic by Article 68 of the French Constitution was incompatible with Article 27 ICC Statute. ${ }^{5}$ Therefore, on 9 July 1999, a law inserting the following provision in the French Constitution was promulgated:

La République peut reconnaître la juridiction de la Cour pénale internationale dans les conditions prévues par le traité signé le 18 juillet $1998 .{ }^{6}$

Although many states have indicated that constitutional immunity might form an obstacle to swift ratification, ${ }^{7}$ the issue has usually not been addressed as squarely as in France. Some states have likewise amended their constitution (e.g. Luxembourg), some have announced that constitutional amendments might be necessary (e.g. Austria, Mexico, Slovenia) while others have stated that amendment of their constitution is (probably) not necessary (e.g. Norway, Spain). Some states have chosen to ratify the Statute first and deal with possible compatibility questions later (e.g. Italy, Belgium). States seem eager to circumvent the issue by, for example, stating that constitutional immunities are only relevant within the internal constitutional order and are therefore not affected by the ratification of the Statute. This argument seems to neglect the actual process of surrender to the ICC - an act covered by Article 27. The surrender of its head of state to the ICC by national authorities is at least in breach of any inviolability the head of state may enjoy within the constitutional order. Admittedly, the mere discussion of the possibility of torture in the Elysee, the White House or Paleis Noordeinde might be seen as to cast a negative light on the dignity of a head of state. However, it is submitted that this evasive attitude is not advancing the

4. Statute of the International Criminal Tribunal for the Former Yugoslavia, annexed to Security Council Resolution 827 (1993); Statute of the International Criminal Tribunal for Rwanda, annexed to Security Council Resolution 955 (1994). See also A. Watts, The Legal Position in International Law of Heads of State, Heads of Government and Foreign Ministers, 247 RdC 13, at 81-84 (1994-III).

5. Conseil Constitutionnel, 22 January 1999 , No $98-408$ DC.

6. Loi constitutionetle no 99-568, J.O. Numero 157, 9 July 1999, 10175.

7. See url supra note 1. 
constructive development of a sound doctrine. ${ }^{8}$ France can be lauded for its expeditiousness in solving the constitutional problems and subsequent ratification of the Statute. Moreover, the openness with which it has approached this delicate issue sets an example to other states. Finally, the fact that many states are confronted with similar problems in ratifying this important treaty might warrant the call for a more consolidated approach. Of course, the scope and extent of constitutional immunities vary greatly from state to state and therefore solutions will vary similarly.

Notwithstanding this lack of open discussion, the widespread manifestation of willingness to overcome difficulties caused by a possible clash between national constitutions and the Rome Statute proves a substantial commitment to the realisation of the International Criminal Court.

\section{ARTICLE 98 ICC STATUTE}

In stark contrast with this willingness to ratify the Statute within due time is the US hostile attitude towards the future criminal court. The US position in the ICC debate and its decision not to sign the Rome Statute has been extensively discussed in doctrine. An earlier editorial in this Journal discussed this position still rather empathetically. It was conceded that

[t]he US cannot be blamed for going to great lengths to keep its soldiers out of harms way $[. .$.$] As the US points out again and again, it bears the lions share of the burden$ of international security. Its soldiers constitute the bulk of many peacekeeping operations. This - and anti-US sentiments in many areas, makes US soldiers as well as civilians an attractive target. ${ }^{9}$

It was, however, also pointed out that the Statute contains several safeguards against frivolous or politicised prosecutions. ${ }^{10}$ It is not necessary to repeat the respective arguments here, as they are common knowledge by now. ${ }^{11}$

The main US objection against the ICC is that the Court will have jurisdiction over nationals of non-state parties when the state on whose territory the alleged atrocities have taken place is party to the Statute. The final US compro-

8. It is interesting to note that the ratification of the 1948 Genocide Convention has not given rise to similar discussions. Art. 4 of the Convention provides that "Persons committing genocide [...] shall be punished, whether they are constitutionally responsible rulers, public officials or private individuals." The UK, for example, has not included this specific article into its domestic implementing legislation, but in most other states the article has not led to discussions on constitutional compatibility.

9. M. Zwanenburg, The Statute for an International Criminal Court and the United States: Peace Without Justice?, 12 LJIL 1, at 6 (1999).

10. $I d$, at $3-6$.

11. See for an overview of the most important arguments R. Wedgwood, The International Criminal Court: An American View, 10 EJIL 93-107 (1999) and G. Hafner et al., A Response to the American View as Presented by Ruth Wedgwood, 10 EJIL 108-123 (1999). 
mise on this issue, tabled only days before the end of the Conference, proposed to exempt from the Court's jurisdiction conduct that arises from the official actions of a non-state party acknowledged as such by that state. ${ }^{12}$ This compromise was, however, rejected. When the US subsequently failed to sign the Rome Treaty, Lloyd Axworthy, the Canadian foreign minister, ventilated the hope that the US would treat the Court with benign neglect, rather than be aggressively opposed. Recent developments have proven this hope to be vain. A vigorous attack against ICC jurisdiction over nationals of non-state parties has been launched at two levels: national as well as international measures have been proposed to prevent the ICC from prosecuting US nationals.

The pivot of this latest attack is Article 98 ICC Statute. This provision addresses the possible conflict between a request for surrender or assistance and a requested state's obligations under international law. Paragraph 1 provides that the Court may not proceed with such a request when this would put the requested state in the position of having to violate its obligations under international with regard to immunities. It has been argued that "this [...] article does not reduce the effect of article 27 in any way". ${ }^{13}$ Although it exceeds the purpose of this editorial to discuss this issue, it is suggested that the widely acknowledged customary law status of Article 27 should lead to the conclusion that there are no immunities under international law for the acts within the jurisdiction of the Court. ${ }^{14}$ There is even support for this conclusion when domestic proceedings are concerned, ${ }^{15}$ but with respect to international proceedings this seems indisputable. Here, Paragraph 2 of Article 98 is under consideration. In effect, this provision obliges the Court to respect treaty-made immunities flowing from international agreements concluded by the requested state. In practice, this provision acknowledges the so-called Status of Forces agreements concluded between a sending state and the requested state. The provision does not affect the Court's initial jurisdiction since it only plays a role at the stage of the request of surrender and does not affect the possibility that other state parties, not under an international obligation to refrain from surrender, will be able to surrender when they obtain jurisdiction over the individual concerned. It is clear, however, that in practice this provision offers a potentially wide loophole to escape the Court's

12. UN Doc. A/CONF.183/C.1/L.90 (1998).

13. K. Prost \& A. Schlunck, in: O. Triffterer (Ed.), Commentary on the Rome Statute (1999), Article 98 , margin No. 2.

14. In this respect Section 70 of the Canadian Crimes Against Humanity Act (Bill C-19) introduced, inter alia, to implement Canada's obligations the Rome Statute and to ensure its ability to co-operate fully with investigations and prosecutions by the ICC should be mentioned. This section ensures that the Canadian State Immunity Act yields to the obligations under ICC Statute.

15. This is not only true for immunities ratione materiae as evidenced by the 1999 Pinochet case but also for immunities ratione personae: compare e.g. F.O. Vicuna, Diplomatic and Consular Immunities and Human Rights, 40 ICLQ 34-48 (1991); Belgium: Loi relative à la répression des infractions graves de droit international humanitaire, 10 February 1999, Moniteur Belge, 23 March 1999, reproduced in 38 ILM 918 (1999). 
jurisdiction. The US is now trying to make use of this provision on the national level and, at the same time, abuse it on the international level.

At the national level Senator Jesse Helms, Chairman of the Senate Foreign Relations Committee is attempting to ensure that the Rome Treaty will be "dead on arrival" ${ }^{16}$ He has described the ICC as "a monster" and has declared it "our responsibility to slay it before it grows to devour us." To this end, Helms has recently presented the "American Servicemembers" Protection Act of 2000" in the US Senate. ${ }^{18}$ The Bill cites as its motive "[the protection of] United States military personnel and other elected and appointed officials of the United States Government against criminal prosecution by an international criminal court to which the United States is not a party". The Bill is an obvious attempt to force the US Government to make full use of the loophole offered by Article 98(2) ICC Statute and put effective pressure on other states to enter into 98(2) agreements with the US. Section 5 of the Act restricts the US participation in UN peacekeeping operations. After the date the Rome Statute enters into effect US military personnel may only participate in a peacekeeping operation authorised by the UN Security Council pursuant to chapter VI or VII when:

- the UN Security Council has permanently exempted US military personnel participating in the operation from criminal prosecution by the ICC for actions undertaken by them in connection with the operation, or

- when the countries in which territory US military personnel participates in the peacekeeping operation is not a party to the ICC or has entered into an agreement in accordance with Article 98 or

- when other appropriate steps have been taken to guarantee that US military personnel participating in the peacekeeping operation will not be prosecuted before the ICC.

Section 7 of the Act provides that, "no United States military assistance may be provided to the government of a country that is a party to the International Criminal Court" with the exception of NATO member states or major nonNATO allies. The President may waive this prohibition when a country has entered into an agreement with the US pursuant to Article 98 .

This legislation was discussed in a, poorly attended, hearing of the Senate Foreign Relations Committee on 14 June 2000. The former Secretary of Defense, Caspar Weinberger, and two representatives from academia, Jeremy Rabkin and Ruth Wedgwood, were invited to attend the meeting. Not as much to

16. Hearing Before the Subcommittee on International Operations of the Committee on Foreign Relations of the United States Senate, 105 ${ }^{\text {th }}$ Cong. $2^{\text {nd }}$ Sess. S. Hrg. 105-724 (1998).

17. Financial Times, 31 July 1998.

18. $106^{\text {th }}$ Cong. $2^{\text {nd }}$ Sess. S. 2726 (2000). See also the already existing 2000-2001 Foreign Retations Authorization Act that prohibits any US funds going to the ICC, unless the Senate has given its advice and consent to the Rome Treaty: S. 886, section 821 . 
engage in a balanced discussion on the features of the Rome Statute and the consequent implications for US military operations, but rather, it seemed, to echo Helms' hostility and paranoia towards the ICC. Only Wedgwood can be said to have given the rabble-rousing Senator some hesitant opposition. On 25 and 26 July the United States House of Representatives' Committee on International Relations held hearings on the Bill. It is interesting to note that US Ambassadorat-large for War Crimes Issues David Scheffer, who led the US delegation to the Rome Conference, testified to oppose to the proposed legislation. He argued that the legislation imposed "unnecessary and dangerous restrictions on national security decision-making" and would moreover "undermine" the US objective to exempt its nationals from ICC jurisdiction rather than further it. He urged for the legislation to be withdrawn in order to free the way for his own efforts, at the international level, to achieve protection for US nationals.

The proposed Act is, to say the least, not commendable in its obvious objective to ensure that US citizens will never be surrendered to the jurisdiction of the ICC, as the effectiveness of the future Court would be undermined when this legislation should be adopted. However, effectively it only formalises the use of the exceptions to the Court's jurisdiction laid down in Articles 16 and 98(2) ICC Statute. The legislation is strictly speaking within the explicit boundaries of the Statute and, hence, cannot be said to attempt to amend the Statute in any way.

The same is, however, not true for the US attack on ICC jurisdiction at the international level. The fifth session of the Preparatory Commission for the International Criminal Court (the Commission) which took place from 12 to 30 June 2000 provided the setting for this attack. The US participates since the Commission consists not only of representatives of states that have signed the Rome Statute but also of states that were invited to participate in the Rome Conference. The June session was devoted to the Elements of Crimes referred to in Article 9 ICC Statute and the Rules of Procedure and Evidence of the Court. At first sight, it might seem unclear how this session should facilitate a renewed attempt to debilitate the jurisdictional rules of the Court. Yet, a US proposal for a Rule to Article 98(2) formed a shrewd first step of a two-phased scheme to do just that. The proposed text of this Rule to Article 98 of the Rome Treaty reads as follows:

The Court shall proceed with a request for surrender or an acceptance of a person into the custody of the Court only in a manner consistent with its obligations under the relevant international agreement. ${ }^{19}$

The second step of the scheme was planned for the sixth session of the Commission, scheduled to take place from 27 November to 8 December of this year, when, inter alia, the Relationship Agreement between the ICC and the UN will

19. See url supra note 1, Documents Section. 
be discussed. The text that would be proposed by the US during that session provides that:

The United Nations and the International Criminal Court agree that the Court may seek the surrender or accept custody of a national who acts within the overall direction of a U.N. Member State, and such directing State has so acknowledged, only in the event (a) the directing State is a State Party to the Statute or the Court obtains the consent of the directing State, or (b) measures have been authorized pursuant to Chapter VII of the U.N. Charter against the directing State in relation to the situation or actions giving rise to the alleged crime or crimes, provided that in connection with such authorization the Security Council has determined that this subsection shall apply. ${ }^{20}$

Read in conjunction, it is evident that these proposals attempt to procure the realisation of an official-act-exception to jurisdiction through the back door. The slightly different wording of the proposal compared to Article 98 itself - the obligations of the requested state under international agreements would be complemented with obligations resting on the Court flowing from international agreements - would ensure that the Relationship Agreement that will be concluded between the UN and the ICC would qualify under Article 98(2). Although formally the proposal is not concerned with jurisdiction, the practical consequences can, however, be equated with a bar to jurisdiction over nationals of non-consenting non-state parties. ${ }^{21}$ This would effectuate a de facto immunity from ICC jurisdiction for US nationals and a de facto amendment of the Rome Statute. Article 121 ICC Statute provides that amendment is not possible within the first seven years after the Statute enters into force and, furthermore, lays down very strict rules for such a procedure. Amendment of the Statute is hence not within the mandate of the Commission.

The US proposal concerning the Rule to Article 98(2) encountered fierce criticism from states as well as NGO's. It can be argued that the proposal does exactly for nationals of non-state parties what Article 27 explicitly forbids: it in effect introduces an immunity for official acts. It is submitted here that this proposal is an aggravated variant of what the Nuremberg precedent and, indeed, the Statute itself forbids since it would be within the competence of the state of nationality itself to determine whether an act qualifies as official. US Ambassador Scheffer has tried to trivialise the objections against the original official act proposal, tabled at the Rome Conference, by stating that "[t]he [...] proposal would require a nonparty state to acknowledge responsibility for an atrocity in order to be exempted, an unlikely occurrence for those who usually commit genocide or other heinous crimes." ${ }^{\prime 22}$ This statement is contested. Did not the Pinochet case,

20. Id.

21. Unless the Security Council authoritizes measures pursuant to Chapter VII UN Charter. This exception would of course not affect the permanent members.

22. D.J. Scheffer, The United States and the International Criminal Court, 93 AJIL 12, at 20 (1999). 
with the Republic of Chile invoking its own immunity for the acts of torture under consideration of the House of Lords in order to free its former head of state, prove the opposite?

When the fifth session of the Commission was concluded on 30 June a compromise on the text of the Rule to Article 98(2) was announced. The final Rule 9.19 to Article 98(2) ICC Statute reads as follows:

The Court may not proceed with a request for the surrender of a pcrson without the consent of a sending State if, under Article 98, paragraph 2, such a request would be inconsistent with obligations under an international agreement pursuant to which the consent of a sending State is required prior to the surrender of that State to the Court.

Portugal, speaking on behalf of the European Union, declared the formula to be the best compromise possible and emphasised that the EU would never accept any interpretation of the Rules that ran counter to the spirit of the Rome Statute. ${ }^{23}$ Although compared to the US proposal the final text of the Rule reduces the chance that the Relationship Agreement between the ICC and the UN will qualify under Article 98, some more room for manoeuvre has undeniably been created. The need for vigilance during the forthcoming session of the Preparatory Commission is definitely still pressing.

\section{ConClusion}

The connection between the two developments described above can be said to be twofold. In the first place, the US proposal for a Rule to Article 98(2) and the subsequent provision in the Relationship Agreement with the UN would have had the effect that the rule encompassed in Article 27 ICC Statute would in practice not apply to nationals of non-state parties. Not because they would be able to invoke their official capacity before the Court but because their official capacity would prevent the Court from requesting their surrender. Secondly, an immense contrast in attitude towards the International Criminal Court and the Rule of Law in general can be said to be presented by the comparison of the sincere efforts of most states to solve the constitutional problems caused by the ratification of the Statute and the latest US efforts to ensure that the ICC will be significantly weakened on its arrival in The Hague.

Rosanne van Alebeek

23. See for both the text of the Rule and the statement of Portugal, Press Release, L/2963 (30 June 2000). 